\title{
25 Research Square \\ Palliative Radiotherapy for Gastric Cancer Bleeding: A Multi-Institutional Retrospective Study.
}

Kazuya Takeda ( $\sim$ takeda7616@gmail.com )

Tohoku University Graduate School of Medicine

Toru Sakayauchi

Osaki City Hospital

Masaki Kubozono

Miyagi Prefecture Cancer Center

Yu Katagiri

Ishinomaki Red Cross Hospital

Rei Umezawa

Tohoku University Graduate School of Medicine

Takaya Yamamoto

Tohoku University Graduate School of Medicine

\section{Yojiro Ishikawa}

Tohoku University Graduate School of Medicine

Noriyoshi Takahashi

Tohoku University Graduate School of Medicine

\section{Yu Suzuki}

Tohoku University Graduate School of Medicine

\section{Keita Kishida}

Tohoku University Graduate School of Medicine

\section{Keiichi Jingu}

Tohoku University Graduate School of Medicine

\section{Research Article}

Keywords: Gastric cancer, Tumor bleeding, Hemostasis, Palliative radiotherapy, Neutrophil-to-lymphocyte ratio (NLR)

Posted Date: January 3rd, 2022

DOI: https://doi.org/10.21203/rs.3.rs-1174198/v1

License: (9) This work is licensed under a Creative Commons Attribution 4.0 International License. 
Version of Record: A version of this preprint was published at BMC Palliative Care on April 12th, 2022. See the published version at https://doi.org/10.1186/s12904-022-00943-2. 


\section{Abstract}

Background: Palliative radiotherapy for gastric cancer bleeding has been reported to be a safe and effective treatment, but predictive factors for achievement of hemostasis and overall survival have not been established.

Methods: In this retrospective study, 120 courses of palliative radiotherapy for gastric cancer bleeding in 117 patients in 4 institutes in Japan were reviewed with approval of the ethical committee in each institute. The rate of achieving hemostasis was evaluated by $50 \%$ or more reduction of red blood cell transfusion before and after the start of radiotherapy, elevation of blood hemoglobin concentration in a period of 4 weeks from the start of radiotherapy or improvement of subjective or objective clinical symptoms in a period of 4 weeks from the start of radiotherapy. Predictive factors for overall survival and achieving hemostasis were investigated with the Cox hazards model.

Results: The median overall survival period was 3.7 months. Multivariate analysis showed that absence of metastatic disease, higher biological effective dose, higher serum albumin level, lower blood urea nitrogen level and lower neutrophil-to-lymphocyte ratio (NLR) were associated with longer overall survival. Elevation of hemoglobin concentration in a period of 4 weeks from the start of radiotherapy (mean concentration: $8.2 \mathrm{~g} / \mathrm{dL}$ vs. $8.9 \mathrm{~g} / \mathrm{dL}, \mathrm{p}=0.006$ ) and decrease in the amount of red cell transfusion from a 4-week period before to a 4-week period after the start of radiotherapy (mean amount: $716 \mathrm{~mL}$ vs. 230 $\mathrm{mL}, \mathrm{p}<0.0001$ ) were observed. The overall rate of achievement of hemostasis was $59.6 \%$. In multivariate analysis, higher biological effective dose was associated with achievement of hemostasis. Grade 2 or higher acute adverse effects related to radiotherapy were observed in $17.5 \%$ of cases in 120 treatment courses. Six cases (5.0\%) had grade 3 or 4 adverse effects including gastric penetration in 1 patient and anorexia requiring total parental nutrition in 3 patients. No grade 5 adverse effects were observed.

Conclusions: Palliative radiotherapy for gastric cancer bleeding seems to be an effective and safe treatment strategy. Higher treatment dose was associated with longer overall survival and a hemostatic effect. Some hematological parameters may predict overall survival, and they would be helpful for deciding the treatment strategy.

\section{Background}

Gastric cancer is the fifth most common malignancy and the second-most common cause of cancer death worldwide. The incidences of gastric cancer are particularly high in East Asian and South American countries. In Japan, 126,009 people were diagnosed with gastric cancer and 44,192 people died from gastric cancer in 2018 [1].

Radiotherapy for gastric cancer is used in preoperative, postoperative, and palliative situations. Palliative radiotherapy for tumor bleeding has been reported to be a safe and effective treatment[2]. Some studies showed that a higher treatment dose is associated with a better clinical response[3], whereas another study showed that a short course and low dose of radiotherapy were adequate for palliative treatment of 
bleeding[4]. There has been no randomized controlled trial to determine the optimal treatment dose. In clinical practice, treatment dose can be decided by the prognosis of the patient with consideration of knowledge about pain control radiotherapy for bone metastases, for which a smaller dose is known to be related to a higher rate of symptom recurrence. However, there is no established method foe predicting the prognosis of patients receiving palliative radiotherapy for gastric bleeding.

In this study, we collected data from multiple centers and investigated the effectiveness of radiotherapy in patients with locally advanced gastric cancer and the prognostic factors in such patients.

\section{Methods}

\section{Study design}

This study was a multi-institutional retrospective study.

\section{Patients}

In this study, the medical records of 117 patients who underwent palliative radiotherapy for bleeding from a gastric neoplasm in 4 institutes in Japan were reviewed.

\section{Radiotherapy}

All patients underwent 3-dimensional conformal radiotherapy (3D-CRT) using computed tomography (CT)-based planning. Measures for respiratory motion using four-dimensional CT were used if possible with consideration of institutional equipment and status of the patient. The definitions of treatment volumes were as follows. Clinical target volume (CTV) was defined as gross tumor volume (GTV) plus a margin of 0 to $1 \mathrm{~cm}$, but setting the whole stomach as CTV was also allowed. Internal target volume (ITV) was defined as CTV plus a margin of 0 to $2 \mathrm{~cm}$ with consideration of tumor respiratory motion and available countermeasures. Planning target volume (PTV) was defined as ITV plus a margin of $1 \mathrm{~cm}$. Modification of target volumes with consideration of the status of the patient was allowed. Treatment was delivered with 2 to 4 beams of 6 to $10 \mathrm{MV} \mathrm{X-rays} \mathrm{generated} \mathrm{in} \mathrm{a} \mathrm{linear} \mathrm{accelerator.} \mathrm{Multiple-field}$ irradiation was used if it was necessary to reduce the dose to the left kidney and bowel. Intensitymodulated radiotherapy (IMRT) was not used in any of the patients. Thirty Gy in 10 fractions delivered over a period of 2 weeks was considered as standard treatment, but physicians decided the treatment dose for each patient with consideration of the patients' condition, tumor pathology, and treatment history.

\section{Follow-up and evaluation}

Hospital patient records were retrospectively reviewed. Data were collected from patient records up to September 30, 2021. To determine the effectiveness of treatment for tumor bleeding, the amount of red blood cell transfusion, blood hemoglobin concentration, and changes in symptoms were assessed. Hemostasis induced by radiotherapy was defined as follows: (1) $50 \%$ or greater reduction in the amount 
of red blood cell transfusion in a period of 4 weeks before and a period of 4 weeks after the start of radiotherapy if the patient received transfusion before the start of radiotherapy, (2) elevation in blood hemoglobin concentration of $1 \mathrm{~g} / \mathrm{dl}$ or more at 4 weeks after the start of radiotherapy if the patient did not receive red blood cell transfusion in a period of 4 weeks before and after the start of radiotherapy, and (3) any improvement in objective clinical symptoms (e.g., disappearance of melena) and subjective clinical findings (e.g., confirmation of hemostasis by endoscopy). Acute adverse effects associated with radiotherapy in a period of 4 weeks after the end of radiotherapy were recorded according to Common Terminology Criteria for Adverse Events (CTCAE) version 5.0.

\section{Statistical analysis}

All statistical analyses were conducted using JMP Pro version 16.0 (SAS Institute Inc.). Predictive factors for hemostasis were investigated using logistic regression. Overall survival was estimated by the KaplanMayer method, and the Cox hazards model was used for univariate and multivariate analyses. Student's t-test or Dunnett's test was used for evaluation of differences in mean values in two groups or multiple groups. A p value less than 0.05 was considered to be statistically significant for each analysis.

\section{Results}

A total of 117 patients were enrolled in this study. Three patients underwent two courses of radiotherapy, and 120 courses of treatment were therefore reviewed. Patients' characteristics are shown in Table 1. 
Table 1

Characteristics of the patients. Values with an asterisk (*) are shown as median values with ranges. NOS: not otherwise specified, BED10: biological effective dose calculated with $\alpha / \beta=10 \mathrm{~Gy}$.

\begin{tabular}{|c|c|c|}
\hline sex & female & $28(23.3 \%)$ \\
\hline & male & $92(76.7 \%)$ \\
\hline age & [years] & $\begin{array}{l}71.0(43.9- \\
95.8)^{\star}\end{array}$ \\
\hline \multirow[t]{5}{*}{ histology } & $\begin{array}{l}\text { primary gastric } \\
\text { adenocarcinoma }\end{array}$ & $106(88.3 \%)$ \\
\hline & residual stomach cancer & $4(3.3 \%)$ \\
\hline & primary gastric carcinoma, NOS & $4(3.3 \%)$ \\
\hline & esophageal cancer & $3(2.5 \%)$ \\
\hline & metastatic carcinoma & $3(2.5 \%)$ \\
\hline \multirow{3}{*}{$\begin{array}{l}\text { metastatic disease at the time of } \\
\text { radiotherapy }\end{array}$} & yes & $91(75.8 \%)$ \\
\hline & no & $28(23.3 \%)$ \\
\hline & unknown & $1(0.8 \%)$ \\
\hline \multirow[t]{3}{*}{ history of any other treatments } & yes & $76(63.3 \%)$ \\
\hline & no & $43(35.8 \%)$ \\
\hline & unknown & $1(0.8 \%)$ \\
\hline serum hemoglobin concentration & {$[\mathrm{g} / \mathrm{dL}]$} & $8.2(4.5-11.8)^{\star}$ \\
\hline transfusion in last 4 weeks & {$[\mathrm{mL}]$} & $560(0-3080)^{\star}$ \\
\hline dose of radiotherapy in $\mathrm{BED}_{10}$ & [Gy] & $39.0(7.8-60.0)^{\star}$ \\
\hline \multirow[t]{2}{*}{ concurrent chemotherapy } & yes & $14(11.7 \%)$ \\
\hline & no & $106(88.3 \%)$ \\
\hline
\end{tabular}

Thirty-one patients (26.5\%) were alive at the time of data cut-off. The median survival period of the patients was 3.7 months. Survival rates at 6 months and 12 months were $37.3 \%$ and $18.6 \%$, respectively (Fig. 1A). Table 2 shows the results of univariate and multivariate analyses to determine predictive factors of overall survival. Parameters with $p$ values $<0.05$ were included into multivariate analysis, in which lymphocyte count and calcium-albumin ratio were excluded as possible confounding factors. In multivariate analysis, absence of metastatic disease, higher biological effective dose, higher serum albumin level, lower blood urea nitrogen level and lower neutrophil-to-lymphocyte ratio (NLR) were 
associated with longer overall survival. Fig. 1B - 1E show Kaplan-Meyer survival curves according to median values of parameters that were significant in multivariate analysis. 
Table 2

Results of univariate and multivariate analysis for predicting overall survival. HR: hazard ratio; $\mathrm{Cl}$ : confidence interval; BED10: biological effective dose calculated with $\alpha / \beta=10 \mathrm{~Gy}$.

\begin{tabular}{|c|c|c|c|c|}
\hline & $\begin{array}{l}\text { univariate } \\
\text { analysis }\end{array}$ & & multivariate & ysis \\
\hline & $\mathrm{HR}(95 \% \mathrm{Cl})$ & $p$ value & $\mathrm{HR}(95 \% \mathrm{Cl})$ & $\begin{array}{l}\mathrm{p} \\
\text { value }\end{array}$ \\
\hline Sex (female / male) & $\begin{array}{l}1.33(0.80- \\
2.12)\end{array}$ & 0.25 & & \\
\hline age & $\begin{array}{l}0.24(0.20- \\
0.29)\end{array}$ & $<0.0001$ & $\begin{array}{l}0.50(0.14- \\
1.79)\end{array}$ & 0.28 \\
\hline $\begin{array}{l}\text { histology (primary gastric adenocarcinoma } \\
\text { / others) }\end{array}$ & $\begin{array}{l}0.76(0.44- \\
1.44)\end{array}$ & 0.36 & & \\
\hline metastatic disease (yes / no) & $\begin{array}{l}1.96(1.17- \\
3.44)\end{array}$ & 0.01 & $\begin{array}{l}2.35(1.27- \\
4.55)\end{array}$ & 0.01 \\
\hline red blood cell transfusion in last 4 weeks & $\begin{array}{l}1.91(1.63- \\
2.24)\end{array}$ & $<0.0001$ & $\begin{array}{l}0.74(0.26- \\
1.89)\end{array}$ & 0.55 \\
\hline history of any other treatments (yes / no) & $\begin{array}{l}1.26(0.81- \\
1.98)\end{array}$ & 0.31 & & \\
\hline biological treatment dose $\left(\mathrm{BED}_{10}\right)$ & $\begin{array}{l}0.06(0.04- \\
0.07)\end{array}$ & $<0.0001$ & $\begin{array}{l}0.09(0.02- \\
0.53)\end{array}$ & 0.007 \\
\hline concurrent chemotherapy (yes / no) & $\begin{array}{l}0.82(0.40- \\
1.51)\end{array}$ & 0.55 & & \\
\hline blood test hemoglobin & $\begin{array}{l}0.65(0.52- \\
0.81)\end{array}$ & 0.0001 & $\begin{array}{l}0.81(0.21- \\
3.12)\end{array}$ & 0.76 \\
\hline hematocrit & $\begin{array}{l}0.61(0.16- \\
2.18)\end{array}$ & 0.45 & & \\
\hline red blood cell count & $\begin{array}{l}0.48(0.17- \\
1.52)\end{array}$ & 0.21 & & \\
\hline white blood cell count & $\begin{array}{l}0.60(0.21- \\
1.53)\end{array}$ & 0.31 & & \\
\hline neutrophil count & $\begin{array}{l}0.69(0.23- \\
1.83)\end{array}$ & 0.48 & & \\
\hline lymphocyte count & $\begin{array}{l}0.39(0.15- \\
0.92)\end{array}$ & 0.04 & - & - \\
\hline platelet count & $\begin{array}{l}2.45(1.00- \\
5.47)\end{array}$ & 0.04 & $\begin{array}{l}1.79(0.64 \text { - } \\
4.67)\end{array}$ & 0.25 \\
\hline calcium & $\begin{array}{l}0.11(0.01- \\
1.17)\end{array}$ & 0.07 & & \\
\hline
\end{tabular}




\begin{tabular}{|c|c|c|c|c|}
\hline \multirow[b]{2}{*}{ albumin } & \multicolumn{2}{|l|}{$\begin{array}{l}\text { univariate } \\
\text { analysis }\end{array}$} & \multicolumn{2}{|c|}{ multivariate analysis } \\
\hline & $\begin{array}{l}0.36(0.22- \\
0.58)\end{array}$ & $<0.0001$ & $\begin{array}{l}0.11(0.02- \\
0.54)\end{array}$ & 0.008 \\
\hline blood urea nitrogen & $\begin{array}{l}6.42(1.56- \\
21.87)\end{array}$ & 0.006 & $\begin{array}{l}6.51(1.70- \\
21.78)\end{array}$ & 0.004 \\
\hline creatinine & $\begin{array}{l}0.34(0.05- \\
2.13)\end{array}$ & 0.27 & & \\
\hline total bilirubin & $\begin{array}{l}2.68(0.58 \text { - } \\
7.93)\end{array}$ & 0.13 & & \\
\hline lactate dehydrogenase & $\begin{array}{l}6.58(1.16- \\
23.18)\end{array}$ & 0.01 & $\begin{array}{l}3.35(0.42- \\
15.45)\end{array}$ & 0.17 \\
\hline C-reactive protein & $\begin{array}{l}12.08(2.32- \\
53.60)\end{array}$ & 0.002 & $\begin{array}{l}3.41(0.47- \\
20.65)\end{array}$ & 0.20 \\
\hline neutrophil-to-lymphocyte ratio & $\begin{array}{l}9.94(2.84- \\
29.59)\end{array}$ & 0.0001 & $\begin{array}{l}6.91(1.36- \\
29.62)\end{array}$ & 0.01 \\
\hline platelet-lymphocyte ratio & $\begin{array}{l}2.49(0.67- \\
6.79)\end{array}$ & 0.12 & & \\
\hline calcium-albumin ratio & $\begin{array}{l}1.84(1.33- \\
2.57)\end{array}$ & 0.0003 & - & - \\
\hline
\end{tabular}

In 120 treatment courses, 85 (70.8\%) cases could be followed up for 4 weeks after the start of radiotherapy. In those cases, the mean amounts of red blood cell transfusion before and 4 weeks after the start of radiotherapy were $716 \mathrm{~mL}$ and $230 \mathrm{~mL}$, respectively ( $<<0.0001$, Fig. $2 \mathrm{~A}$ ). A decrease of more than $50 \%$ in the amount of transfusion was achieved in $71 \%$ of the 85 cases. The mean hemoglobin concentration at the start of radiotherapy was $8.2 \mathrm{~g} / \mathrm{dL}$. Significant decline in the mean hemoglobin concentration was observed in 4 weeks before the start of radiotherapy and significant recovery was observed in 4 weeks after the start of radiotherapy ( $p=0.002$ and 0.006 , respectively, Fig. 2B). Subjective and objective improvements of clinical symptoms were accessed in all of the 120 treatment courses, and improvement was achieved in 26 cases (21.7\%). Hemostasis was achieved in 59.6\% of the 120 cases. Table 3 shows the results of univariate and multivariate analyses to predict achievement of hemostasis. In multivariate analysis, higher biological effective dose was associated with achievement of hemostasis. The rates of hemostasis were $71.1 \%$ in patients who received 39 Gy in $\mathrm{BED}_{10}$ or a higher dose and $32.4 \%$ in patients who received less than $39 \mathrm{~Gy}(\mathrm{p}<0.0001$, Fig. 3). 
Table 3

Results of univariate and multivariate analysis for predicting treatment response. OR: odds ratio; $\mathrm{Cl}$ : confidence interval; BED10: biological effective dose calculated with $\alpha / \beta=10 \mathrm{~Gy}$.

\begin{tabular}{|c|c|c|c|c|}
\hline & $\begin{array}{l}\text { univariate } \\
\text { analysis }\end{array}$ & & $\begin{array}{l}\text { multivariate } \\
\text { analysis }\end{array}$ & \\
\hline & OR $(95 \% \mathrm{Cl})$ & $\begin{array}{l}p \\
\text { value }\end{array}$ & OR $(95 \% \mathrm{Cl})$ & $\begin{array}{l}\mathrm{p} \\
\text { value }\end{array}$ \\
\hline Sex (female / male) & $\begin{array}{l}0.42(0.18- \\
0.99)\end{array}$ & 0.05 & $\begin{array}{l}0.44(0.17- \\
1.12)\end{array}$ & 0.08 \\
\hline age & $\begin{array}{l}1.44(0.24- \\
8.64)\end{array}$ & 0.69 & & \\
\hline $\begin{array}{l}\text { histology (primary gastric adenocarcinoma } \\
\text { / others) }\end{array}$ & $\begin{array}{l}0.78(0.25- \\
2.50)\end{array}$ & 0.68 & & \\
\hline metastatic disease (yes / no) & $\begin{array}{l}0.74(0.31- \\
1.78)\end{array}$ & 0.50 & & \\
\hline red blood cell transfusion in last 4 weeks & $\begin{array}{l}6.17(0.85- \\
44.81)\end{array}$ & 0.07 & & \\
\hline history of any other treatments (yes / no) & $\begin{array}{l}0.91(0.42- \\
1.94)\end{array}$ & 0.80 & & \\
\hline biological treatment dose $\left(\mathrm{BED}_{10}\right)$ & $\begin{array}{l}65.33(4.38- \\
974.14)\end{array}$ & 0.002 & $\begin{array}{l}43.44(2.48- \\
761.55)\end{array}$ & 0.01 \\
\hline concurrent chemotherapy (yes / no) & $\begin{array}{l}0.91(0.29- \\
2.81)\end{array}$ & 0.87 & & \\
\hline $\begin{array}{l}\text { blood } \quad \text { hemoglobin } \\
\text { test }\end{array}$ & $\begin{array}{l}0.63(0.08- \\
5.10)\end{array}$ & 0.66 & & \\
\hline hematocrit & $\begin{array}{l}0.47(0.05- \\
4.18)\end{array}$ & 0.50 & & \\
\hline red blood cell count & $\begin{array}{l}0.64(0.08- \\
4.90)\end{array}$ & 0.67 & & \\
\hline white blood cell count & $\begin{array}{l}1.28(0.25- \\
6.61)\end{array}$ & 0.77 & & \\
\hline neutrophil count & $\begin{array}{l}1.13(0.20- \\
6.39)\end{array}$ & 0.89 & & \\
\hline lymphocyte count & $\begin{array}{l}1.40(0.33- \\
5.88)\end{array}$ & 0.65 & & \\
\hline platelet count & $\begin{array}{l}0.39(0.08- \\
1.81)\end{array}$ & 0.23 & & \\
\hline calcium & $\begin{array}{l}5.88(0.13- \\
261.97)\end{array}$ & 0.36 & & \\
\hline
\end{tabular}




\begin{tabular}{|c|c|c|c|c|}
\hline & $\begin{array}{l}\text { univariate } \\
\text { analysis }\end{array}$ & & $\begin{array}{l}\text { multivariate } \\
\text { analysis }\end{array}$ & \\
\hline albumin & $\begin{array}{l}9.57(1.31- \\
69.82)\end{array}$ & 0.03 & $\begin{array}{l}3.68(0.36 \text { - } \\
37.19)\end{array}$ & 0.27 \\
\hline blood urea nitrogen & $\begin{array}{l}0.13(0.01- \\
1.45)\end{array}$ & 0.10 & & \\
\hline creatinine & $\begin{array}{l}0.40(0.03- \\
5.72)\end{array}$ & 0.50 & & \\
\hline total bilirubin & $\begin{array}{l}2.65(0.06- \\
123.70)\end{array}$ & 0.62 & & \\
\hline lactate dehydrogenase & $\begin{array}{l}0.05(0.00- \\
3.61)\end{array}$ & 0.17 & & \\
\hline C-reactive protein & $\begin{array}{l}0.04(0.00- \\
0.81)\end{array}$ & 0.04 & $\begin{array}{l}0.16(0.00- \\
7.72)\end{array}$ & 0.36 \\
\hline $\begin{array}{l}\text { neutrophil-to-lymphocyte } \\
\text { ratio }\end{array}$ & $\begin{array}{l}0.42(0.04- \\
4.95)\end{array}$ & 0.49 & & \\
\hline platelet-lymphocyte ratio & $\begin{array}{l}0.19(0.01- \\
3.68)\end{array}$ & 0.27 & & \\
\hline calcium-albumin ratio & $\begin{array}{l}0.38(0.02- \\
6.02)\end{array}$ & 0.49 & & \\
\hline
\end{tabular}

Grade 2 or higher acute adverse effects related to radiotherapy occurred in $17.5 \%$ of the cases. 6 cases (5.0\%) had grade 3 or higher acute adverse effects, including grade 3 anorexia requiring total parenteral nutrition in 5 patients and grade 4 gastric perforation treated with emergency surgery in 1 patient. No grade 5 adverse effects were observed.

\section{Discussion}

In this multicenter retrospective study, patients who underwent palliative radiotherapy for gastric neoplasm bleeding were reviewed. Hemostasis was achieved in $59.6 \%$ of treatment courses after palliative radiotherapy, and $5.0 \%$ of the cases had grade 3 or higher acute adverse effects. One of the largest retrospective studies on palliative radiotherapy for gastric cancer bleeding was carried out by Tey et al.[5]. They analyzed data for 115 advanced symptomatic gastric cancer patients and reported that the response rate to radiotherapy for bleeding was $80.6 \%$. Viani et al. conducted a meta-analysis including 11 studies and reported that the overall response rate for bleeding was 77.7\%[3]. In the present study, some of the patients were transferred to other hospitals immediately after radiotherapy and could not be followed up. This may be associated with the lower rate of hemostasis. In fact, the response rate was $77.8 \%$ when we included only 85 patients who could be followed up for more than 4 weeks, and that rate is consistent with the response rates in previous studies. A recently published prospective observational 
study showed the same tendency, with the overall response rate at 4 weeks being $53 \%$ and the perprotocol response rate at 4 weeks being $78 \%[6]$.

Multivariate analysis in our study showed that higher treatment dose was an independent predictor for achieving a hemostatic effect. For gastric cancer patients, a meta-analysis has shown that $30 \mathrm{~Gy}$ or a higher dose in $\mathrm{BED}_{10}$ was associated with bleeding response, being consistent with the results of the present study.

On the other hand, the efficacy of a low dose and a short course of radiotherapy has been established by randomized control trials in patients with inoperative non-small cell lung cancer[7, 8] and patients with bladder carcinoma[9]. One study showed that a single course or multiple courses of radiotherapy at a dose of $6 \mathrm{~Gy}$ in 3 fractions was safe and effective for bleeding gastric carcinoma[4]. Generally, a higher dose seems to have a better effect on gastric cancer bleeding, but it is reasonable to consider a short course of radiotherapy for some patients with limited prognosis. We revealed some predictive factors besides lower $\mathrm{BED}_{10}$ for shorter overall survival including presence of metastatic disease, lower serum albumin concentration, higher blood urea nitrogen level and higher neutrophil-to-lymphocyte ratio. Recently, some hematological parameters have been shown to be related to prognosis in cancer patients treated with radiotherapy[10]. In the present study, among 4 patient parameters (metastatic disease, serum albumin, blood urea nitrogen and NLR), NLR showed the most significant difference in overall survival between two groups. A relationship between high NLR and poor prognosis has recently been shown in various types of cancer[11]. NLR has been reported to be prognostic factor in gastric cancer patients treated with chemotherapy, chemoradiotherapy and surgery[12,13], but there has been no report for patients treated with palliative radiotherapy. The results of the present study suggest that NLR predicts prognosis and might be helpful for choosing the treatment dose.

In the present study, grade 3 or higher acute adverse effects occurred in 6 patients (5.0\%). Five of those patients had grade 3 anorexia and 1 patient had grade 4 gastric perforation. Considering the site of disease, perforation seems to be an inevitable adverse effect to some extent. Overall, the rate of acute adverse effects seemed to be acceptable.

We recognize some limitations in our study. First, there were data defects because of the study being a retrospective multicenter study. We could not acquire follow-up data for some patients who were transferred to other hospitals soon after completion of radiotherapy. Secondly, most of the patients were treated with a dose of $30 \mathrm{~Gy}$ in 10 fractions (64.2\%) or a dose of $20 \mathrm{~Gy}$ in 5 fractions (19.2\%), and it was therefore difficult to examine the efficacy of single-dose radiotherapy or high-dose radiotherapy over 39 Gy in $\mathrm{BED}_{10}$.

\section{Conclusions}

In conclusion, palliative radiotherapy for gastric cancer bleeding seems to be an effective and relatively safe treatment strategy. A dose of $30 \mathrm{~Gy}$ in 10 fractions or a higher dose was associated with longer 
overall survival and a hemostatic effect.

\section{Abbreviations}

3D-CRT

3-dimensional conformal radiotherapy

CT

computed tomography

CTV

clinical target volume

GTV

gross tumor volume

ITV

internal target volume

PTV

planning target volume

IMRT

intensity-modulated radiotherapy

CTCAE

Common Terminology Criteria for Adverse Events

NOS

not otherwise specified

$\mathrm{BED}_{10}$

biological effective dose calculated with $\alpha / \beta=10 \mathrm{~Gy}$.

\section{Declarations}

\section{Ethical approval and consent participate}

All procedures performed in studies involving human participants were in accordance with the ethical standards of the institutional and/or national research committee and with the 1964 Helsinki declaration and its later amendments or comparable ethical standards. This study was approved by the Tohoku University Hospital Institutional Review Board (2021-1-452). Informed consent for each patient was waived because this is a retrospective observatory study. Information on the study was presented on the institutional web site, and the right to decline participating in this study was indicated for each patient.

\section{Consent for publication}

Not applicable.

\section{Availability of data and materials}


The datasets used and/or analyzed during the current study are available from the corresponding author on reasonable request.

\section{Competing interests}

The authors declare that they have no competing interests.

\section{Funding}

This study was not funded by any sources.

\section{Authors' contributions}

KT proposed the study and was responsible for the overall study coordination including data collection, transcription of the data, statistical analysis and writing of the initial draft of the manuscript. TS, MK and YK reviewed the study concept and critically revised the manuscript. RU, TY, YI, NT, YS and KK revised the manuscript. KJ supervised the study and participated in the revision of the initial concept and the manuscript. All authors read and approved the final manuscript.

\section{Acknowledgements}

Not applicable.

\section{References}

1. Welfare M of H Labour and. Cancer Statistics. Cancer Information Service, National Cancer Center, Japan.

2. Tey J, Soon YY, Koh WY, Leong CN, Choo BA, Ho F, et al. Palliative radiotherapy for gastric cancer: a systematic review and meta-analysis. Oncotarget. 2015;5:25797-805.

3. Viani GA, Arruda CV, Hamamura AC, Faustino AC, Danelichen AFB, Matsuura FK, et al. Palliative radiotherapy for gastric cancer: Is there a dose relationship between bleeding response and radiotherapy? Clinics. 2020;75:e1644.

4. Kawabata H, Uno K, Yasuda K, Yamashita M. Experience of Low-Dose, Short-Course Palliative Radiotherapy for Bleeding from Unresectable Gastric Cancer. J Palliat Med. 2017;20:177-80.

5. Tey J, Choo BA, Leong CN, Loy EY, Wong LC, Lim K, et al. Clinical Outcome of Palliative Radiotherapy for Locally Advanced Symptomatic Gastric Cancer in the Modern Era. Medicine. 2014;93:e118.

6. Saito T, Kosugi T, Nakamura N, Wada H, Tonari A, Ogawa H, et al. Treatment response after palliative radiotherapy for bleeding gastric cancer: a multicenter prospective observational study (JROSG 17-3). Gastric Cancer. 2021; Online ahead of print. 
7. Bleehen N, Girling D, Machin D, Stephens R. A Medical Research Council (MRC) randomised trial of palliative radiotherapy with two fractions or a single fraction in patients with inoperable non-small-cell lung cancer (NSCLC) and poor performance status. Brit J Cancer. 1992;65:934-41.

8. Party R to the MRC by its LCW. Inoperable non-small-cell lung cancer (NSCLC): a Medical Research Council randomised trial of palliative radiotherapy with two fractions or ten fractions. Brit $\mathrm{J}$ Cancer. 1991;63:265-70.

9. Duchesne GM, Bolger JJ, Griffiths GO, Roberts JT, Graham JD, Hoskin PJ, et al. A randomized trial of hypofractionated schedules of palliative radiotherapy in the management of bladder carcinoma: results of medical research council trial BA09. Int J Radiat Oncol Biology Phys. 2000;47:379-88.

10. Takeda $\mathrm{K}$, Umezawa R, Takahashi N, Matsushita H, Kozumi M, Ishikawa $\mathrm{Y}$, et al. Impact of change in serum albumin level during and after chemoradiotherapy in patients with locally advanced esophageal cancer. Esophagus. 2018;15:190-7.

11. Cupp MA, Cariolou M, Tzoulaki I, Aune D, Evangelou E, Berlanga-Taylor AJ. Neutrophil to lymphocyte ratio and cancer prognosis: an umbrella review of systematic reviews and meta-analyses of observational studies. Bmc Med. 2020;18:360.

12. Arigami T, Uenosono Y, Ishigami S, Okubo K, Kijima T, Yanagita S, et al. A Novel Scoring System Based on Fibrinogen and the Neutrophil-Lymphocyte Ratio as a Predictor of Chemotherapy Response and Prognosis in Patients with Advanced Gastric Cancer. Oncology. 2016;90:186-92.

13. Miyamoto R, Inagawa S, Sano N, Tadano S, Adachi S, Yamamoto M. The neutrophil-to-lymphocyte ratio (NLR) predicts short-term and long-term outcomes in gastric cancer patients. Eur J Surg Oncol. 2018;44:607-12.

\section{Figures}


A

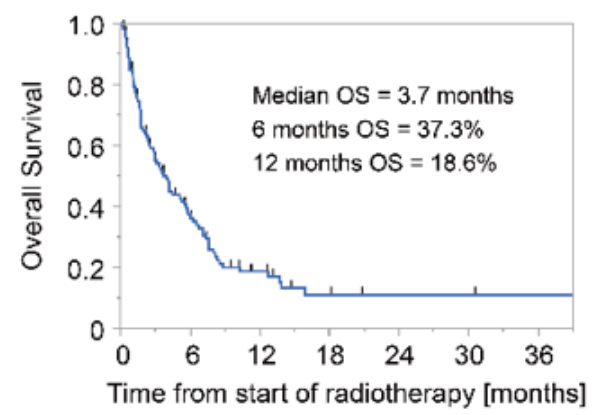

D

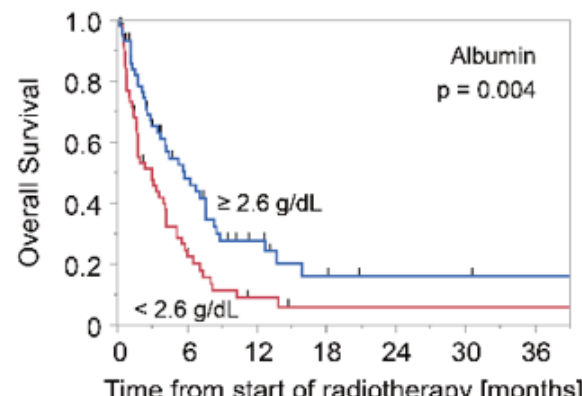

B

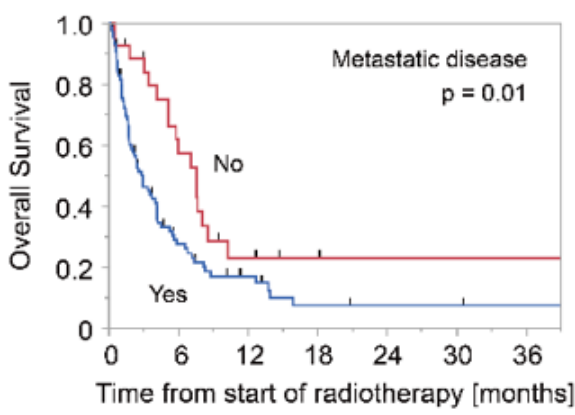

$\mathrm{E}$

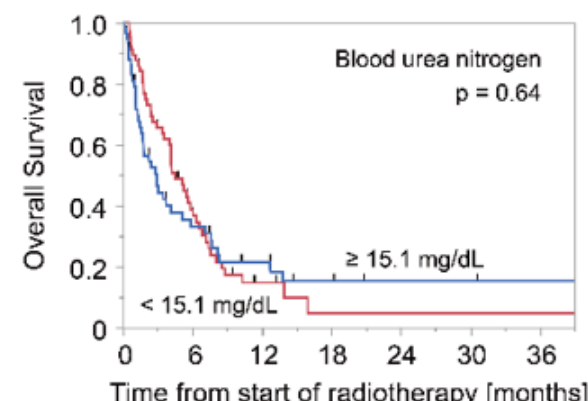

C

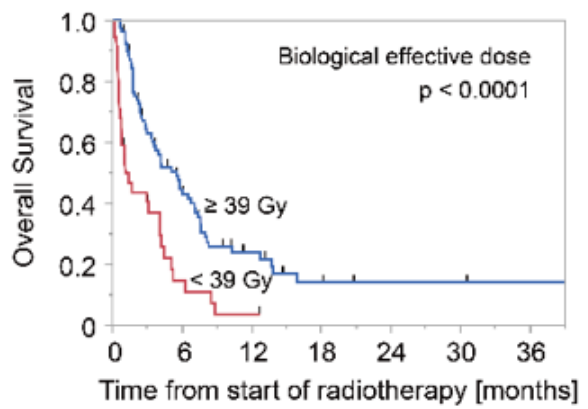

$\mathrm{F}$

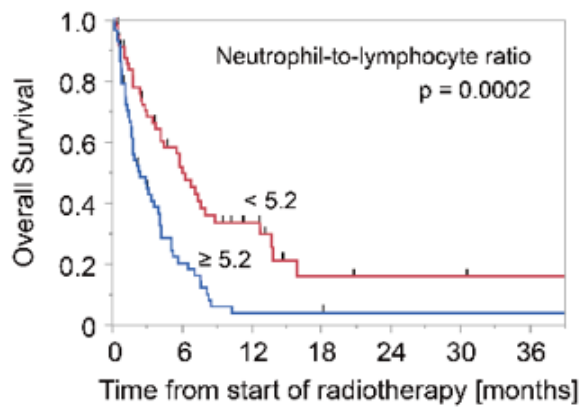

Figure 1

Survival curves plotted by the Kaplan-Meyer method for a all patients and according to $b$ existence of metastatic disease, c biological effective dose, $d$ median value of serum albumin, e median value of blood urea nitrogen and $f$ median value of neutrophil-to-lymphocyte ratio. Each $p$ value was calculated by the log-rank test.

A

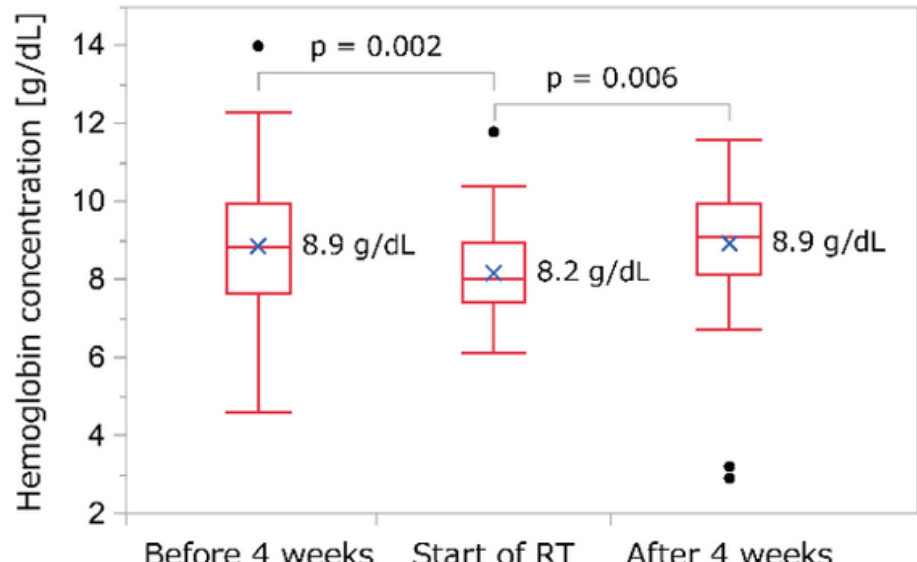

Before 4 weeks Start of RT After 4 weeks
B

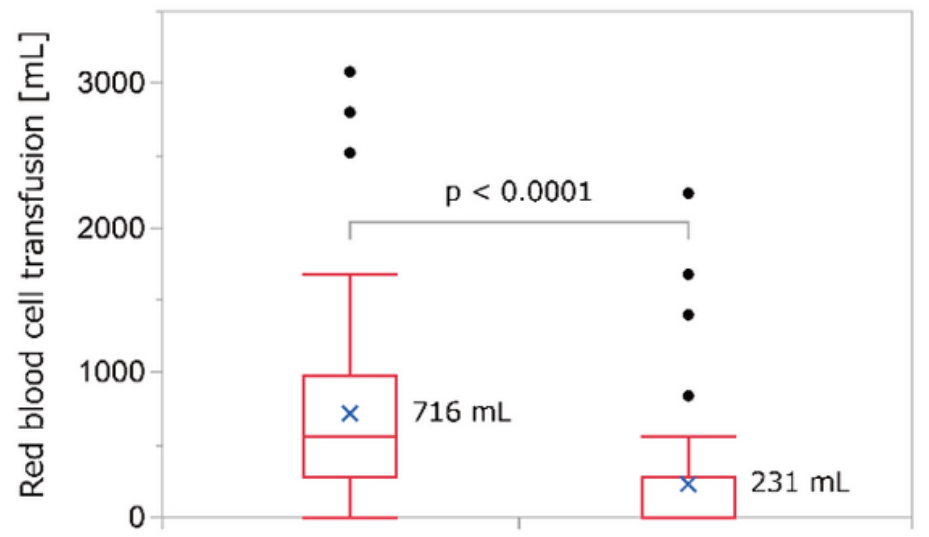

Pre 4 weeks

Post 4 weeks

\section{Figure 2}

Treatment evaluation. a Changes in hemoglobin concentration. b Amounts of red blood cell transfusion before and after 4 weeks from start of radiotherapy plotted with box plots. Cross marks show mean values. Dunnett's test and Students' t-test were used. 


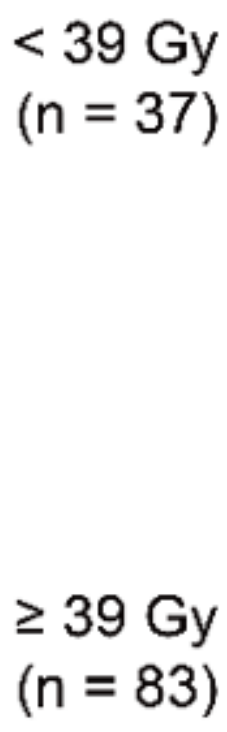

$32.4 \%$

$p=0.0001$

$71.1 \%$

\section{Achievement of hemostasis}

\section{Figure 3}

Achievement of hemostasis by treatment dose. Two-sided Fischer's exact test was used to evaluate the differences in rates of response. 